\title{
En diskursteoretisk analyse af artikulationen af læringsrelaterede begreber i relation til informationssøgning
}

\author{
Af Kristine Gazel
}

\section{Introduktion}

Denne artikel behandler begrebet læring i relation til begrebet informations $\varnothing$ gning i biblioteks $-\mathrm{og}$ informationsvidenskaben (LIS). Det centrale spørgsmål er, hvilke konsekvenser anvendelse af begreber, der er importeret fra læringsteori, har for forståelsen af og konstruktion af LIS-begreber såsom 'informationssøgning', 'information', 'bruger' og 'bibliotekar'.

Dette afdækkes gennem en analyse af Carol Kuhlthaus Seeking Meaning: a process approach to library and information services (Kuhlthau, 1993). Denne monografi har opnået stor opmærksomhed i det danske biblioteksvæsen siden sin udgivelse. På grund af dens virkningshistorie er det relevant at diskutere, hvilke konsekvenser, der er affødt af den diskursive artikulation af læringsrelaterede begreber i relation til informationssøgning, der forekommer i monografien. Jeg tager udelukkende analytisk udgangspunkt i denne tekst, hvilket betyder at jeg ikke inddrager andre af Kuhlthaus tekster.
Udgangspunktet er ikke, hvorfor læringsteori er relevant i relation til informationssøgning, men hvordan begreber hentet fra læringsteori relateres til informationssøgning. Artiklen handler derfor ikke om læringsteori, men om anvendelsen i LIS af begreber importeret fra læringsteori. Derfor anvender jeg termen laringsrelaterede begreber. Med dette udgangspunkt bliver problemstillingen:

- Hvilke konsekvenser har artikulation af læringsrelaterede begreber for kernebegreberne $\mathrm{i}$ informationssøgningsforskningen i LIS?

\section{Metode}

Analysen er en diskursteoretisk baseret tekstanalyse af Kuhlthau (1993). Min metode er derfor at anvende diskursteoretiske begreber som udgangspunkt for en tekstanalyse. Valget af diskursteorien som udgangspunkt for tekstanalysen betyder, at der i artiklen forekommer et bestemt begrebsapparat, der har bestemte konsekvenser for beskrivelsen og fortolkningen af analysens genstande. Dette begrebsapparat udfoldes som en forudsætning for selve analysen for 
at gøre applikationen af de diskursteoretiske begreber så gennemskuelig som overhovedet mulig.

\section{De diskursteoretiske begreber}

\subsection{Diskursive artikulationer}

Det diskursteoretiske diskursbegreb er hjørnestenen i diskursteorien. Imidlertid lancerer Torfing fire forskellige definitioner af diskursbegrebet (Torfing, 1999, s. 85, 86, 87, 300). Det er nødvendigt at skabe en syntetisk definition, hvori alle aspekter af diskursbegrebet afspejles, hvorfor jeg definerer diskurs som:

"En helhed, der består af forskelsrelationer mellem betegnende sekvenser, der giver sociale elementer betydning. Da det er helheden af de betegnende sekvenser, der udgør diskursen, eksisterer der ikke et samlende eller fikserende centrum, der kan fastlåse betydning endeligt, hvorfor diskursen aldrig er fuldstændigt lukket. Endelig eksisterer der ikke ud fra det diskursteoretiske diskursbegreb en distinktion mellem det diskursive og det ikke-diskursive." (Gazel, 2003, s. 19).

Det er vigtigt at pointere, at det handler om konstruktion af betydning. En diskurs er en helhed, der fikserer betydning indenfor et givent felt. I nærværende sammenhæng er det væsentligt at forstå, hvordan diskurser etableres gennem diskursive artikulationer, snarere end at forstå selve diskursbegrebet. En diskurs er et resultat af en artikulation, hvorigennem elementer ( $\mathrm{fx}$ begreber) sættes i bestemte relationer til hinanden, hvorved de fikseres som momenter i en diskurs. Den bestemte måde, hvorpå de relateres til hinanden igennem konkrete artikulationer giver dem betydning. Laclau \& Mouffe skriver:

"I denne diskussion vil vi bruge artikulation om enhver praksis, som etablerer en relation mellem elementer, således at deres identitet modificeres som følge af denne artikulatoriske praksis. Den strukturerede totalitet, som resulterer af denne artikulatoriske praksis, vil vi kalde for diskurs. De differentielle positioner vil vi - i den udstræk- ning de optræder som artikulerede inden for en diskurs - kalde for momenter. I modsætning hertil vil vi kalde enhver forskel som ikke er diskursivt artikuleret for element." (Laclau \& Mouffe, 2002, s. 52).

Opsummering: Elementer er ufikserede betegnere, der endnu ikke er artikulerede og dermed blevet indlemmet i en konkret diskurs. Sker dette fikseres de som momenter, der er bestemte positioner i diskursen. De er altså defineret via deres relation til og forskel fra andre momenter i diskursen. Det er vigtigt at fremhæve formuleringen i det ovenstående citat om, at den artikulatoriske praksis modificerer elementernes betydning ved at etablere en bestemt relation mellem dem (ibid.). Det samme element kan som forskellige momenter $\mathrm{i}$ forskellige diskurser have forskellig betydning, fordi de indgår i forskellige relationer. Dette implicerer, at forskellige diskurser kæmper om at artikulere elementerne entydigt, således, at præcis én betydning hersker. I den sammenhæng er begrebet ydende betegner centralt:

"A signifier that is over owed with meaning because it is articulated differently within different discourses." (Torfing, 1999, s. 301).

En ydende betegner er et element, der i høj grad er åbent for forskellig betydnings-tilskrivning, og som forskellige diskurser kæmper om at artikulere på netop deres måde, og dermed give en bestemt, entydig betydning (Winther Jørgensen \& Phillips, 1999, s. 39). Et nodalpunkt er en ydende betegner, der er blevet fikseret som et "krystalliseringspunkt" $i$ en konkret diskurs, mens en ydende betegner henviser til den kamp, der foregår om betydning mellem ere diskurser (ibid.). Der eksisterer nogenlunde det samme forhold mellem ydende betegnere og nodalpunkter, som mellem elementer og momenter. En ydende betegner er et privilegeret element, ligesom nodalpunktet er et privilegeret moment, omkring hvilket betydning fikseres ved at relatere andre momenter i en betydningskæde og dermed give hele diskursen sin identitet. 


\subsection{Det diskursive felt}

Af ovenstående definition fremgår, at der ikke eksisterer et fikserende centrum. I stedet træder nodalpunktet, som kun foreløbigt fikserer betydning; en endelig totalisering kan ikke finde sted. En totalisering er en fastlåsning af betydning indenfor et område, hvorved en entydig identitet/betydning fremkommer, og andre, uønskede betydningsmuligheder udelukkes. Men med fraværet af et privilegeret centrum er en endelig totalisering umulig (Torfing, 1999, s. 91-92).

Det betyder, at der vil være noget, der undslipper betydningsfiksering. De kun delvise fikseringer af betydning producerer et overskud af betydning, og dette overskud kaldes det diskursive felt (Torfing, 1999, s. 92). Det hedder det diskursive felt for at understrege, at de elementer, der ikke aktuelt er indlemmet i en konkret diskurs ikke er ekstra- eller ikke-diskursive, men befinder sig i et ufikseret terræn; distinktionen mellem diskurs og det diskursive felt sker ud fra graden af fikserethed og ufikserethed (Torfing, 1999, s. 92-93)

Det diskursive felt $\mathrm{g} \varnothing \mathrm{r}$ den delvise fiksering af betydning, som de konkrete diskurser skaber, både mulig og umulig. Det diskursive felt er diskursens konstitutive ydre, idet diskursen konstituerer sig i forhold til de betydninger, der udelukkes eller som ikke indlemmes i den aktuelle diskurs (Winther Jørgensen \& Phillips, 1999, s. 37). Det diskursive felt gør diskursen mulig, fordi det er det ydre, som den konstituerer sig i forhold til, og det som tilvejebringer det felt af elementer, hvoraf diskursen indlemmer nogle og udelukker andre. Men, det konstitutive ydre gør også diskursen umulig: netop fordi det diskursive felt er det ydre, som diskursen konstituerer sig i forhold til, er den i altid fare for at blive undermineret af dette ydre (ibid. s. 38). Der skabes endvidere et felt af konkurrerende diskurser, der kæmper om at fastlåse betydning. Men spørgsmålet er, som det diskursive felt består af:

"[E]t temmeligt ustruktureret hav af al mulig betydningsdannelse, eller om det i sig selv er struktureret af de givne konkurrende diskurser." (Winther Jørgensen og Phillips, 1999, s. 37).

Som svar på dette spørgsmål låner Winther Jørgensen og Phillips begrebet diskursorden fra Fairclough. Diskursorden skal så betegne et afgrænset antal diskurser, der kæmper i samme terræn (ibid. s. 38), mens det diskursive felt kan bruges til at betegne al mulig betydningsdannelse.

\subsection{Differens - og akvivalenslogikkens funktion}

Disse to logikker får diskursen til at "hænge sammen" (Laclau og Mouffe, 2002, s. 53). De er faktorer, der medvirker til at få diskursen til at fremstå som en helhed (Torfing, 1999, s. 99). Differenslogikken defineres som:

\footnotetext{
"A way of relating discursive moments in and through their mutual differences. The logic of difference constructs a relational 'totality'. The differential relations between the discursive moments are constitutive of their very identity." (Torfing, 1999, s. 300).
}

Der er en sammenhæng mellem den artikulatoriske praksis og differenslogikken på den måde, at når elementer modificeres til momenter, og disse positioneres via deres forskelsrelationer, som det sker i den artikulatoriske praksis, er det et udtryk for at differenslogikken udfoldes. Ækvivalenslogikken defineres som:

"The logic of equivalence constructs a chain of equivalential identities among different elements that are seen as expressing a certain sameness." (Torfing, 1999, s. 301).

Hvor differenslogikken etablerer relationer, der er baseret på forskel - forskelsrelationer - er ækvivalenslogikken et udtryk for en modsatrettet strategi, idet den etablerer relationer, der er baseret på lighed - ækvivalensrelationer. Men der er ikke en simpel lighed mellem disse ækvivalerede identiteter, da de kun er ens i ét perspektiv, men de er forskellige i andre (Torfing, 1999, s. 97). Det bør understreges, at differens - og ækvivalenslogikkerne ikke er gensidigt udelukkende, tværtimod er der altid et 
komplekst samspil mellem de to (Howarth \& Stavrakakis, 2000, s. 12). En given social identitet vil kunne inkluderes i både en ækvivalensrelation og en forskelsrelation. Det afhænger af de diskursive strategier, der udfoldes. Den diskursive strategi, der ligger til grund for differenslogikken, er at skabe social identitet ved at fiksere betydning. (Torfing, 1999, s. 97). Mens formålet med den diskursive strategi, der ligger til grund for udfoldelsen af ækvivalenslogikken, er at skabe en negativ identitet; diskursivt at konstituere en anti-identitet:

"[T]he expansion of a chain of equivalence is always related to the construction of a constitutive outside". (Torfing, 1999, s. 97).

En diskurs afgrænses ved at definere grænserne for diskursen ud fra det, som er hinsides disse grænser (Torfing, 1999, s. 124). En diskurs konstruerer sine grænser ved at ekskludere en radikal andethed, der intet har tilfælles med den diskurs, fra hvilken den er ekskluderet, og som derfor udgør en konstant trussel til denne diskurs. På samme tid negerer og konstituerer den derfor diskursens grænser og identitet.

\subsection{Hegemoni}

Hegemonibegrebet refererer til konstruktionen af en dominerende diskursiv formation, der stræber efter at etablere og vedligeholde politisk, så vel som moralsk og intellektuelt lederskab. Hegemoni defineres således:

"[T]he expansion of a discourse, or a set of discourses, into a dominant horizon of social orientation and action by means of articulating unfixed elements into partially fixed moments in a context crisscrossed by antagonistic forces." (Torfing, 1999, s. 101).

Forskellen mellem diskurs - og hegemonibegrebet ligger i det forhold, at hegemoniske interventioner finder sted i et terræn, der er gennemsyret af antagonisme. Social antagonisme opstår, når to diskurser forhindrer hinanden i at opnå fuld identitet, idet de søger at udelukke hinanden på samme terræn, og dermed blokerer hinandens fulde udfoldelse. For at entydighed kan (gen)skabes, må udfoldelsen af den hegemoniske intervention indbefatte, at uønsket identitet udelukkes (Winther Jørgensen og Phillips, 1999, s. 60). Det er derfor formålet med den hegemoniske intervention at fastlåse betydning, at skabe entydighed på tværs af diskurser, der antagonistisk støder sammen. Laclau \& Mouffe opstiller nogle betingelser for, om man kan tale om hegemonisk artikulation; nemlig tilstedeværelsen af social antagonisme, ustabile grænser og etableringen af ækvivalensrelationer som følge af ustabiliteten (Laclau \& Mouffe, 2002, s. 90), samt dislokation, der defineres som:

"A destabilization of a discourse that results from the emergence of events that cannot be domesticated, symbolized or integrated within the discourse in question." (Torfing, 1999, s. 301).

En hegemonisk intervention vil forsøge at genoprette entydigheden ved at reartikulere de ydende elementer og betegnere, der ikke længere kan rummes i den diskurs, der er blevet forstyrret af den dislokative kraft (Torfing, 1999, s. 195). Dislokation repræsenterer den kontingens og uafgørlighed, som hegemoniske interventioner etableres på baggrund af (Torfing, 1999, s. 109). Men dislokation er ikke udelukkende en negativ kraft. På den ene side er dislokation en trussel mod sociale identiteter, men den er også muligheden for at disse kan forandres via en reartikulation (Howarth \& Stavrakakis, 2000, s. 13).

\subsection{Subjektet}

Subjektet defineres ud fra den diskurs, i hvilken det indtager en subjektposition (Winther Jørgensen \& Phillips, 1999, s. 53). Subjektet er defineret relationelt ligesom de andre momenter i diskursen. Det afvises, at subjektet er bestemt ud fra én bestemt subjektposition (Howarth \& Stavrakakis, 2000, s. 13). Tværtimod er subjektet fragmenteret, hvilket betyder, at det positioneres af mange forskellige diskurser (Winther Jørgensen \& Phillips, 1999, s. 53). Subjektet er delvist determineret af de subjektpositioner, de indtager i konkrete diskurser, men netop fordi disse aldrig er endeligt lukkede, er der mulighed for at de dislokeres, og derved gives 
subjektet mulighed for at identificere sig med andre identiteter, samt at agere som hegemoniske agenter, der af Torfing defineres som:

"A political agency striving for hegemony" (Torfing, 1999, s. 302).

I nærværende kontekst definerer jeg Kuhlthau som en hegemonisk agent, der fikserer elementer til momenter $\mathrm{i}$ en diskursiv artikulation, mens brugeren ses som et subjekt, der i Kuhlthaus konkrete fors $\emptyset \mathrm{g}$ på hegemonisk intervention er positioneret på en bestemt måde.

\section{Det diskursive terræn}

Jeg bruger det diskursive terræn som en samlebetegnelse for begreberne det diskursive felt og diskursorden, da det er relevant at tale både om diskursorden og om det diskursive felt i forhold til den kontekst, Kuhlthau opererer i.

Kuhlthau (Kuhlthau, 1993) hører hjemme i forskningsområdet Information Behaviour Research (IBR), idet hun artikulerer elementer, der er kernebegreber i dette forskningsområde. IBR har interesseret informationsvidenskabelige forskere gennem 40 år under forskellige betegnelser og med fokus på forskellige forskningsobjekter (Wilson, 1997). Disse forskningsobjekter - 'informationssøgning', 'informationsbrug', 'informationsbehov' - definerer jeg som ydende betegnere.

IBR er en diskursorden, i hvilken der foregår diskursive kampe om at betydningsudfylde disse begreber entydigt. Men også LIS fungerer som diskursorden i forhold til artikulation af disse begreber, idet der kæmpes om at artikulere elementer til momenter mellem og på tværs af forskellige forskningstraditioner i LIS. LIS kan defineres som et uafgørligt terræn, idet der er divergenser mellem forskellige opfattelser af LIS og dets underdiscipliner (Hjørland, 2000; Ingwersen, 1995).

Jeg skelner mellem diskursive artikulationer - som Kuhlthau (1993) er et eksempel på - og diskurser, der er etablerede som diskursive horisonter for betydning, handling og kommunikation, i.e. hegemoniske diskurser. Et eksempel er det kognitive synspunkt i LIS, som Frohmann (1992) dekonstruerer via en Foucault-inspireret tilgang. Et andet eksempel er det fysiske paradigme (Ellis, 1992). Disse diskurser kæmper om fastlåsning af betydningen af elementer og ydende betegnere i LIS. Hertil kommer, at konkrete diskursive artikulationer trækker på, reartikulerer og dekonstruerer disse diskurser.

Kuhlthau henter de læringsrelaterede begreber som elementer i et diskursivt felt af al mulig anden betydning og fikserer dem i sin konkrete diskursive artikulation. Kuhlthau trækker altså elementer ind fra tre forskellige diskursive områder: Information Behaviour Research, LIS og det diskursive felt af al mulig betydningsdannelse, hvorfra hun henter de læringsrelaterede begreber. Grænserne mellem de to diskursordner og det diskursive felt er imidlertid ikke hårdt optrukne, men ydende og uafgørlige, ligesom grænsen mellem diskurser og det diskursive felt.

\section{Kuhlthaus diskursive projekt}

\subsection{Usikkerhedsprincippet}

Tuominen mener ikke, at det interessante er Kuhlthaus intentioner, men resultatet af hendes diskursive projekt (Tuominen, 1997, s. 354). Alligevel er det relevant at opridse hendes intentioner. Kuhlthau foreslår en procesorienteret teori, der kan forme de praksisser, der finder sted omkring biblioteks- og informationsservice (Kuhlthau, 1993, s. $\mathrm{xv}$ ). Formuleringen af denne teori tager udgangspunkt i observationer af, at brugere synes usikre, forvirrede og desorienterede i forhold til informationssøgning (Kuhlthau, 1993, s. xviii). Hun ønsker at finde ud af, hvordan brugere opfatter informationssøgningen og indleder en undersøgelse, der, ud fra konstruktivistisk orienterede læringsbegreber, har til formål at definere en informationssøgningsmodel ud fra brugernes oplevelser: Det er et brugercentreret perspektiv, i modsætning til et systemcentreret perspektiv. 
Resultatet er ISP-modellen, der beskriver informationssøgning som en proces, der udgøres af seks faser eller trin, hver karakteriseret af henholdsvis et kognitivt, et emotionelt og et handlingsorienteret aspekt, og hver relateret til bestemte opgaver og attituder (Kuhlthau, 1993, s. xx-xxi). Hertil formuleres en procesteori som udgøres af et usikkerhedsprincip (Kuhlthau, 1993, s. xxii-xxiii). Formålet med etableringen af usikkerhedsprincippet er at redefinere traditionelle biblioteksservicer som referencearbejde og brugerundervisning, samt bibliotekarens rolle i forhold til brugeren. Dette har konsekvenser for, hvordan 'informationssøgning', 'information', 'brugeren' og 'bibliotekaren' positioneres som momenter i Kuhlthaus diskursive artikulation.

\subsection{Fra et brugerperspektiv til artikulation af lae- ringsrelaterede begreber}

Spørgsmålet er, hvordan forbindelsen mellem brugerperspektivet og de valgte læringsrelaterede begreber etableres. Først formuleres en modsætning mellem det bibliografiske paradigme - der er koncentreret om informationssystemer, og om information som håndgribelige kilder og ressourcer - og det brugercentrede perspektiv - som foretrækkes (Kuhlthau, 1993, s. 1). Denne modsætning løber som en rød tråd igennem monografien.

Forbindelsen mellem det brugercentrerede perspektiv og importen af de læringsrelaterede begreber knyttes med udgangspunkt i Sense Making: et perspektiv, hvor informationssøgning ses som en konstruktionsproces, og hvor brugerens personlige synspunkt og søgen efter mening er central (Kuhlthau, 1993, s. 3). Her anslås temaet informationssøgning som læring og konstruktion. Sense Making og Meaning Seeking er tæt forbundne, da de handler om, at brugeren søger eller skaber mening ud fra information. Derved sker et skift i fokus fra information til mening: Den personlige mening, der søges og skabes gennem informationss øgningsprocessen får lige så stor betydning som indholdet af tekster:

"The personal meaning that the user seeks from the information becomes as critical a considera- tion for library and information services as the content represented in texts." (Kuhlthau, 1993, s. 4).

Det væsentlige er ikke information i sig selv, men hvad det kan bruges til for brugeren i konstruktionsprocessen:

"The process of construction within information seeking involves fitting information in with what one already knows and extending this knowledge to create new perspectives." (Kuhlthau, 1993, s. $4)$.

Netop dette at anvende information som udgangspunkt for udvidelse af personlig viden, er for Kuhlthau konstruktion:

"It is the individual formulation of a personal perspective or focus from the information gathered in order to create something new, a least for him or herself, that fits with the notion of construction." (Kuhlthau, 1993, s. 4).

Til forståelsen af informationssøgning som en konstruktionsproces hører, at den er holistisk. Det vil sige, at den både indbefatter kognitive, emotionelle og handlingsmæssige aspekter. Derfor artikuleres elementer indenfor LIS og IBR, der opfatter informationssøgning som en intellektuel eller kognitiv proces. Specielt elementer, der er forbundet med det kognitive synspunkt (Belkin, 1990) artikuleres; videnstrukurer (Kuhlthau, 1993, s. 5), anomalous state of knowledge (ASK) (ibid.) og endelig Taylors levels of information (Kuhlthau, 1993, s. 6). Hertil kommer begrebet anxiety, der belyser det emotionelle aspekt, og har med usikkerhed at gøre (Kuhlthau, 1993, s. 8).

Det at anskue informationssøgning som en konstruktionsproces implicerer et syn på brugeren som følende usikkerhed, nervøsitet og forvirring. Et usikkerhedsprincip er allerede formuleret i LIS, men dette reartikuleres for at omfatte et brugercentreret perspektiv på informationssøgning: 
"A more holistic view of information seeking incorporates the experience of interacting thoughts, actions, and feelings in the process of construction. Uncertainty initiates the process, and anxiety and an unsettling discomfort may be expected in the early stages. The principle of uncertainty may include the uncertainty of choices of each individual user within a search for information. It can be concluded then that an information search is a learning process in which the choices along the way are dependent on personal constructs rather than one universal predictable search for everyone.” (Kuhlthau, 1993, s. 9).

Argumentationen for at etablere en forbindelse mellem et brugercentreret synspunkt og artikulation af de læringsrelaterede begreber følger altså dette mønster:
Brugercentreret syn på informationssøgning $=$ Sense Making $=$ konstruktionsproces $=$ holistisk proces, der indeholder tanker, handlinger og især følelser $=$ usikkerhedsprincippet $=$ personlig læringsproces.

\section{De læringsrelaterede begreber}

Her præsenteres de læringsrelaterede begreber, som Kuhlthau artikulerer i relation til elementerne 'informationssøgning', 'information', 'brugeren' og 'bibliotekaren', som derved betydningsfikseres som momenter på bestemte måder. De læringsrelaterede begreber, der artikuleres og importeres af Kuhlthau, er optegnet i figur 1. I første kolonne oplistes de læringsteoretikere, der er ophavsmænd til de pågældende begreber, $\mathrm{i}$ anden kolonne selve de læringsrelaterede begreber og endelig i tredie kolonne de begreber i LIS/IBR, som berøres af anvendelsen af de læringsrelaterede begreber.

\begin{tabular}{lll}
\hline Lærings-teoretiker & Læringsrelateret begreb & LIS-begreb \\
\hline Dewey & $\begin{array}{l}\text { Re eksion/ Re ective Thinking } \\
\text { 'Beyond the information given' }\end{array}$ & $\begin{array}{l}\text { Informationssøgning } \\
\text { Information }\end{array}$ \\
Kelly & Konstruktion/ Phases of Construction & Informationssøgning \\
Bruner & Fortolkning/Interpretative Task & $\begin{array}{l}\text { Informations } \emptyset \text { gning } \\
\text { Information }\end{array}$ \\
Vygotsky & Zonen for nærmeste udvikling & Bibliotekar - bruger \\
Schön & Re ekterende praktiker & Bibliotekar - bruger \\
Bruner/ Piaget & Kognitiv udvikling & Bibliotekar- bruger \\
\hline
\end{tabular}

Fig. 1: Oversigt over laringsrelaterede begreber og de momenter de relateres og giver identitet til $i$ Kuhlthaus (Kuhlthau, 1993) artikulation. 
Som det fremgår af figuren, er det de læringsteoretiske begreber lånt af Dewey, Kelly og Bruner, der artikuleres som momenter i relation til informationssøgning. Læringsrelaterede begreber lånt fra Vygotsky, Schön og Piaget/Bruner artikuleres i relation til bibliotekar/bruger-forholdet. Jeg forholder mig ikke til deres "egentlige" betydning. Det er Kuhlthaus artikulation af dem som elementer i relation til de udvalgte LIS-begreber, der er relevant, ikke den måde de artikuleres af deres ophavsmænd (for en nærmere beskrivelse henvises til Kuhlthau (1993) og Gazel (2003)).

\section{Den diskursteoretiske analyse}

Fire begreber er valgt som omdrejningspunkt for den diskursteoretiske analyse, hvori de analyseres som momenter. Formålet er at undersøge, hvordan de konstrueres og modificeres som følge af artikulationen af de læringsrelaterede begreber, samt hvilke diskursive strategier, der er i funktion og hvilke betydninger der udelukkes.

De fire begreber er: 'informationssøgning', 'information' 'brugeren' og 'bibliotekaren'. At jeg netop har valgt disse begreber skyldes, at:

- De fremstår som væsentlige for Kuhlthau selv.

- De berøres direkte af de læringsrelaterede begreber, som Kuhlthau importerer i sin diskursive artikulation, da deres betydning modificeres som følge af artikulationen.

- De er væsentlige kernebegreber i IBR og i LIS. Det vil sige, at de i de diskursordener, hvorfra de er artikuleret, er elementer, der især er åbne for betydningstilskrivning og som der især at kamp om at fiksere entydigt: De er ydende betegnere.

\section{1 'Informationss $\phi$ gning'}

I den diskursteoretiske analyse af informationssøgning tager jeg afsæt i følgende punkter:

- Udfoldelse af ækvivalenslogikken 'Informationssøgning' som læring.

- Udfoldelse af differenslogikken ISP-modellens faser og aspekter som værende forskellige og adskilte.

Kuhlthau anvender i sin konstruktion af 'informationssøgning' både ækvivalens- og differenslogikken. Som nævnt er de ikke gensidigt udelukkende. Jeg anvender dem analytisk som forskellige diskursive strategier, der har forskellige funktioner, og som koncentreres om de forskellige momenter på forskellige måder.

Gennemgangen af, hvordan Kuhlthau bevæger sig fra et brugercentreret perspektiv til at artikulere læringsrelaterede begreber, viste, at argumentationen følger dette mønster:

Brugercentreret syn på informationssøgning = Sense Making $=$ konstruktionsproces $=$ holistisk proces, der indeholder tanker, handlinger og især følelser $=$ usikkerhedsprincippet $=$ personlig læringsproces.

'Informationssøgning' artikuleres som en læringsproces:

"It can be concluded then, that an information search is a learning process ..." (Kuhlthau, 1993, s. 9).

Ifølge Winther Jørgensen \& Phillips (1999, s. 59) anvendes ækvivalenslogikken til at indholdsudfylde nodalpunkter ved at ækvivalere dem med andre betegnere. Ækvivaleringen af informationssøgning med læring har det formål at konstruere momentet informationssøgning som en læringsproces, hvorved momentets identitet fikseres entydigt. Der skabes en kæde af relationer baseret på ligheder mellem forskellige elementer. Elementerne 'informationss $\varnothing g n-$ ing', 'Sense Making', 'konstruktion' og 'læring' ækvivaleres, og de betydningsforskelle, der i andre sammenhænge understreges, ophæves. Det følger heraf, at fx opfattelser af informationssøgning som 'information retrieval' eller 'document retrieval' udelukkes, når formålet med informationssøgning er læring - ikke information i sig selv. 


\begin{tabular}{|c|c|c|c|c|c|c|c|}
\hline Stages & $\begin{array}{l}\text { Task } \\
\text { Initiation }\end{array}$ & $\begin{array}{l}\text { Topic } \\
\text { Selection }\end{array}$ & $\begin{array}{l}\text { Prefocus } \\
\text { Exploration }\end{array}$ & $\begin{array}{l}\text { Focus } \\
\text { Formulation }\end{array}$ & $\begin{array}{l}\text { Information } \\
\text { Collection }\end{array}$ & $\begin{array}{l}\text { Search } \\
\text { Closure }\end{array}$ & $\begin{array}{l}\text { Starting } \\
\text { Writing }\end{array}$ \\
\hline Feelings & Uncertainty & Optimism & $\begin{array}{l}\text { Confusion } \\
\text { Frustration } \\
\text { Doubt } \\
\end{array}$ & Clarity & $\begin{array}{l}\text { Sense of } \\
\text { direction/ } \\
\text { Confidence }\end{array}$ & Relief & $\begin{array}{l}\text { Satisfacton/ } \\
\text { Dissatisfaction }\end{array}$ \\
\hline \multirow{2}{*}{ Thoughts } & \multicolumn{4}{|l|}{ Ambiguity } & \multicolumn{3}{|l|}{ Specificity } \\
\hline & \multicolumn{7}{|c|}{ Increased interest } \\
\hline Actions & \multicolumn{4}{|c|}{ Seeking relevant information } & \multicolumn{3}{|c|}{ Seeking pertinent information } \\
\hline
\end{tabular}

Figur 2: Kuhlthaus ISP-model. Gengivet efter: Figure 3-1: Model of the Information Search Process (Kuhlthau, 1993, s. 43) NB: her er en syvende fase medtaget; en sidste, hvor informationss $\varnothing$ gningsprocessen afsluttes og en skrivefase begyndes.

Modellen (figur 2 ovenfor) konstrueres gennem artikulationen af de læringsrelaterede begreber, der er blevet lånt fra Dewey, Kelly og Bruner. Det mest iøjnefaldende karakteristikum ved Kuhlthaus model er, at den er faseopdelt. Dette stammer fra Kuhlthaus artikulation af Deweys Re ective Thinking, Kellys Phases of Construction og Bruners Interpretative Task, og er bestemmende for hele strukturen. Hertil kommer, at den er lineær. Dette er bemærkelsesværdigt $\mathrm{i}$ betragtning af at konstruktionsprocessen (og læringsprocessen) beskrives som en cyklus:

"The process of construction incorporates a cycle of acting and re ecting, feeling and formulating, predicting and choosing, and interpreting and creating." (Kuhlthau, 1993, s. 31).

Især er fase 4 interessant, da den er omdrejningspunktet for hele processen. Momentet 'focus formulation' er artikuleret ud fra elementet 'hypotese', der importeres fra både Dewey, Kelly og Bruner. Omdrejningspunktet i modellen er momentet 'Formulering af fokus'. Her bør brugerens følelse af usikkerhed forsvinde til fordel for sikkerhed:

"A clear focus enables a person to move on to the next stage, just as a hypothesis initiates testing in the process of construction." (Kuhlthau, 1993, s. 49).

Hvis dette ikke sker får brugeren problemer under resten af informationssøgnings-processen (ibid). Den faseopdelte struktur betyder, at informationssøgningsprocessen artikuleres som et facit, som noget brugeren skal opleve på en bestemt måde, og i en bestemt rækkefølge. Den overordnede opgave er, at bevæge sig fra usikkerhed til sikkerhed, og at forstå opgaverne i de enkelte faser (Kuhlthau, 1993, s. 41).

Modellen afspejler, at det er en holistisk proces, der omfatter både tanker, følelser og opgaver/handlinger. Det kognitive aspekt er artikuleret ud fra Deweys 'Re ective thinking', samt elementer hentet fra det kognitive synspunkt og det følelsesmæssige aspekt er artikuleret udfra Kellys "Phases of Construction". I forbindelse med artikulationen af de læringsrelaterede begreber lånt af Bruner gøres opmærksom på, at de tre dimensioner ikke kan skilles ad; de er en forenet helhed. Hertil kommer, at det er en meget dynamisk proces, hvor de enkelte aspekter og faser rodes sammen (Kuhlthau, 1993, s. 26). 
Alligevel skilles både aspekterne og faserne ad i artikulationen af ISP-modellen, hvorfor jeg mener, at der er tale om udfoldelsen af en differenslogik, fordi der i artikulationen af ISP-modellen fikseres momenter på ganske bestemte positioner i forhold til hinanden. Det er via deres forskelsrelationer i modellen, at de forskellige momenter får betydning og identitet. Der er forskel på de forskellige faser, de forskellige aspekter, de emotionelle indstillinger og de forskellige opgaver og strategier. På grund af disse forskelle giver det mening at se informationssøgning som en proces, hvori brugeren bør forandres af bevægelsen fra usikkerhed til sikkerhed. Brugeren determineres af de forskellige faser i informationssøgningsprocessen.

\section{2 'Information'}

I analysen af momentet 'information' tages afsæt i tre punkter:

- Udfoldelse af ækvivalenslogikken forskellige typer og kategorier af 'information' udelukkes med det bibliografiske paradigme.

- Udfoldelse af ækvivalenslogikken 'information' som mening/ fortolkning.

- 'Information' som medicin.

Der er ere strategier i spil om momentet 'information'. Først det, der udelukkes: det bibliografiske paradigme, og de forståelser af information, hvormed det ækvivaleres. Som nævnt opstilles der en modsætning mellem det bibliografiske paradigme og det brugercentrede perspektiv. Denne modsætning etableres også mellem fysisk og intellektuel adgang til information. Hertil kommer modsætningen mellem sikkerhed og orden overfor usikkerhed:

"The bibliographic paradigm is based on certainty and order, whereas the user's constructive process is characterized by uncertainty and confusion." (Kuhlthau, 1993, s. 8).

Det bibliografiske paradigme og dets syn på information står i modsætning til det at lære fra information. Der konstrueres derfor en kontrast mellem det at lokalisere information og det at lære fra information gennem informationssøgning:

"[T]he quality of the process has more impact on learning than does the quality of the sources. Therefore mediation in the bibliographic paradigm of locating sources is likely to be inadequate to address the process of learning from information." (Kuhlthau, 1993, s. 58).

Og:

"The bibliographic paradigm projects an image of the task of information seeking that is primarily to gather and collect information rather than be a series of task within a constructive process." (Kuhlthau, 1993, s. 119-120).

Der skabes to betydningskæder, der opstilles som modsætninger til hinanden, og hvor den sidste udelukkes:

Det brugerorienterede perspektiv $=$ formidling af intellektuel adgang til information $=$ information som udgangspunkt for læring = informationssøgning som læringsproces = usikker, frustrerende proces.

\section{Versus}

Det bibliografiske paradigme $=$ systemperspektiv $=$ formidling af fysisk information $=$ information som håndgribelig og kilde/ressource = informationssøgning som lokalisering af information = ligetil, sikker og ordentlig proces.

Ækvivalenslogikken anvendes som diskursiv strategi for at skabe en anti-identitet. Kuhlthau definerer grænserne for sin diskursive artikulation ved at konstruere det, der er udenfor hendes konkrete diskursive artikulation som en radikal andethed: det bibliografiske paradigme, og de betydninger af informationssystem, information, formidling og informationssøgning, som ækvivaleres med det bibliografiske paradigme. 
Men hvilken betydningsfiksering af momentet 'information' foretrækkes? Som ovenfor citeret lægges der mere vægt på kvaliteten af informationssøgningsprocessen end på kvaliteten af de dokumenter og kilder, der ligger til grund for den information, der skal indlæres og anvendes af brugeren.

Kuhlthaus artikulation synes at repræsentere et skisma $\mathrm{i}$ forhold til, hvad der er genstandsfeltet for domænet LIS. Definitionen af LIS og dets underområder/ genstandsfelter er et uafgørligt spørgsmål. Det er væsentligt at holde fast $\mathrm{i}$ 'information' som et centralt moment i LIS, og at være bevidst om kvaliteten og mangfoldigheden af de typer af dokumenter, der er kilder for informationsbrug og genstande for informationssøgning. Problemet er imidlertid, at der ikke er enighed om, hvad 'information' er. Buckland (1991) skriver at:
"An exploration of information runs into immediate difficulties. Since the notion of information is meaningful only in relation to someone informed, to the reduction of ignorance and of uncertainty, it is ironic that the term information is itself ambiguous and used in different ways." (Buckland, 1991, s. 3).

Formålet med Bucklands monografi er at afklare begreberne, hvorfor han opstiller en matrix model, hvori informationsbegrebet er opdelt efter to dimensioner; håndgribeligt/uhåndgribeligt og entitet/ proces, som vist i figur 3. Figuren er en klassifikation og dermed udtryk for en bestemt artikulation og betydningsfiksering af 'information'. I forhold til Kuhlthaus konkrete artikulation, er de betydninger af 'information', som udelukkes, dem i højre side af i figuren: forståelsen af information som noget håndgribeligt, noget man kan behandle og håndtere.

Table 1.1

Four Aspects of information

\begin{tabular}{l|l|l} 
& \multicolumn{1}{|c}{$\begin{array}{c}\text { INTANGIBLE } \\
\text { Information-as-knowledge } \\
\text { Knowledge } \\
\text { ENTITY }\end{array}$} & $\begin{array}{l}\text { TANGIBLE } \\
\text { Information-as-thing } \\
\text { Data, document, } \\
\text { recorded knowledge } \\
\text { (Chapters 5 \& 6) }\end{array}$ \\
\hline PROCESS & $\begin{array}{l}\text { Information-as-process } \\
\text { Becoming informed } \\
\text { (Chapter 11) }\end{array}$ & $\begin{array}{l}\text { Information Processing } \\
\text { Data processing, document } \\
\text { processing, knowledge } \\
\text { engineering (Chapter 12) }\end{array}$
\end{tabular}

Figur 3: Figuren viser fire aspekter af, hvordan information kan opfattes. Gengivet efter Table 1.1: Four Aspects of Information (Buckland, 1991, s. 6). 
Den betydningsfiksering af 'information', som Kuhlthau foretrækker, er det som i Bucklands figur svarer til Information-as-process. Processen med at lære fra og fortolke information er vigtigere end selve informationen. Her er læringsrelaterede begreber, der lånes af Dewey og Bruner om at gå 'beyond the information given' $\mathrm{g}$ 'the interpretative task' relevante, idet de artikuleres for at betydningsudfylde momentet information. Konsekvensen af dette er, at det som er interessant ikke er information $i$ sig selv - information som dokument eller kilde - men information som mening eller fortolkning af dokumentet eller kilden.

Kuhlthau skelner ikke eksplicit mellem viden og information, hvorved de ækvivaleres. Dog skelnes der i Kuhlthaus artikulation af ASK-hypotesen (Kuhlthau, 1993, s. 5) mellem viden og information sådan, at viden er det personen kun mangelfuldt besidder - og information er det som personen har brug for i forhold til at råde bod på den anormale situation. ASK-hypotesen er et element, der er artikuleret fra det kognitive synspunkt, hvorfor det kan være interessant se på, hvordan denne diskurs betydningsudfylder 'information'. Udfra Capurros (Capurro, 1992, s. 87) og Taljas (Talja, 1997, s. 67-68) fortolkninger kan det konstateres, at 'information' i det kognitive synspunkt får betydning via sin relation til brugeren. Dette er fuldstændigt konsistent med den opfattelse af informationsbegrebet, som Kuhlthau artikulerer ud fra de læringsrelaterede begreber hun låner fra Bruner. Det betyder, at konstruktionen af momentet 'information' som brugerens konstruktioner, meninger og fortolkninger, ikke er afgørende ny i LIS. Artikulationen af 'information' bekræfter en allerede etableret betydningsfiksering af dette moment, idet Kuhlthau trækker på det kognitive synspunkt, og den betydningsfiksering af 'information', der er artikuleret i denne diskurs.

Konstruktionen af 'information' som medicin, er resultatet af artikulationen af begrebet 'kognitiv udvikling', der er lånt af Piaget/Bruner. Det hænger også sammen med artikulationen af 'den re ekterende praktiker', der betyder, at bibliotekaren positioneres som en læge, der ordinerer medicin til brugeren, der på sin side positioneres som en klient eller endog en patient. På den måde er information som dokumenter og medier en form for medicin, der "ordineres" af bibliotekaren til brugeren i de forskellige faser af informationssøgningsprocessen for at afhjælpe brugerens følelser af frustration, usikkerhed etc. (Kuhlthau, 1993, s. 136). Det er bibliotekaren, der definerer, hvilken type information, der er nødvendig i de forskellige faser af informationssøgningsprocessen.

Dette står i modsætning til 'information' som mening og fortolkning, da det i denne sammenhæng netop er information $\mathrm{i}$ form af dokumenter, medier etc., der er centralt. Dette er et eksempel på, at betydningsfiksering indenfor Kuhlthaus konkrete diskursive artikulation er uafgørlig på trods af, at en diskursiv artikulation netop er et udtryk for et fors $\varnothing \mathrm{g}$ på at skabe entydighed.

\section{3 'Brugeren'}

Analysen af 'brugeren' tager udgangspunkt i:

- Subjektposition 'Brugeren' positioneres som værende suverænt individuelt fortolkende $o g$ usikker.

Det diskursteoretiske begreb, der er relevant i forbindelse med analysen af 'brugeren' er begrebet subjektposition. Subjektet defineres ud fra den diskurs, i hvilken det indtager en subjektposition, og hvorved det er defineret relationelt ligesom de andre momenter i diskursen. Den subjektposition 'brugeren' positioneres i er ikke entydig. Tilsyneladende positioneres 'brugeren' som det suverænt fortolkende individ i kraft af læringsbegreberne, der handler om 're eksion', 'konstruktion' og 'fortolkning'. Brugeren er i centrum som den, der fortolker og konstruerer mening ud fra information. Det er brugeren, der er den re eksivt tænkende, den konstruerende, den fortolkende: Den der skal gennemgå de nødvendige faser af tænkning, følelser og de bestemte opgaver på hvert trin i processen. 
Informationssøgningsprocessen er en rejse, hvor det er brugerens opgave via læring at bevæge sig fra en tilstand af usikkerhed og forvirring til en tilstand af forståelse og sikkerhed. Konstruktions- og fortolkningsprocessen defineres som at gå hinsides information for at skabe noget, der er unikt for den enkelte bruger (Kuhlthau, 1993, s. 23, 25, 114 ). Selvom der tilsyneladende ikke er noget facit i forhold til den enkelte persons fortolkning eller konstruktion (ibid. s. 114), er der tale en normativ proces, idet den enkelte person selv skal finde sin vej fra usikkerhed til forståelse.

Af positioneringen af 'brugeren' som en person, der subjektivt og individuelt søger information følger, at vedkommende står alene. Det er paradoksalt, at Kuhlthau på samme tid positionerer brugeren som suveræn og individuelt fortolkende, og som følge heraf fratager ham/hende muligheden for at kommunikere og forhandle fortolkningen af information med andre. Det vil sige - undtagen bibliotekaren, der har den rette professionelle kapacitet til at hjælpe, til at ordinere informationen (Tuominen, 1997, s. 356; Kuhlthau, 1993, s. 133). Brugeren konstrueres som "alene og usikker", som en der har brug for hjælp, hvorved der etableres en ulige magtrelation mellem brugeren og bibliotekaren. Der findes en parallel til denne paradoksale positionering i Frohmanns definiton af det kognitive synspunkts positionering af brugeren som værende "oplyst uvidende" (Frohmann, 1992, s. 397). På en gang erkender 'brugeren' i Kuhlthaus artikulation sin usikkerhed og er dermed oplyst eller vidende om den. På den anden side defineres 'brugeren' som famlende og forvirret.

Spørgsmålet er, hvorvidt 'brugeren' er passivt determineret i en bestemt subjektposition i Kuhlthaus artikulation. Jeg mener, at Kuhlthau fikserer 'brugeren' $\mathrm{i}$ en position, der er foretrukken $\mathrm{i}$ hendes konkrete diskursive artikulation. Brugeren er defineret af faserne i informationssøgningsprocessen og igennem den bevægelse fra usikkerhed til sikkerhed, som han/hun forventes at foretage. Brugeren er determineret i forhold til informationssøgningsprocessen og ikke mindst af sin relation til bibliotekaren.

\section{4 'Bibliotekaren'}

Analysen af 'bibliotekaren' tager udgangspunkt i:

- Differenslogik 'Brugeren' og 'bibliotekaren' defineres og konstrueres som værende forskellige, hvorved de giver identitet til hinanden.

Relationen mellem 'brugeren' og 'bibliotekaren' defineres gennem anvendelse af differenslogikken som diskursiv strategi, og tager udgangspunkt i de læringsrelaterede begreber lånt fra Vygotsky, Schön, og Piaget/Bruner. 'Brugeren' og 'bibliotekaren' er positioneret $i$ et gensidigt afhængighedsforhold, hvor de definerer hinanden via deres forskelle.

Ved at trække på 'zonen for nærmeste udvikling' og en analyse af lægers zoner for behandling (Kuhlthau, 1993, s. 156) artikuleres og identificeres fem zoner for bibliotekarens intervention i brugerens informationssøgningsproces (Kuhlthau, 1993, s. 158). Disse beskrives som følger:

"In the first zone (Z1), the problem is self-diagnosed, the need for information self determined and a search self-conducted. In each of the other zones (Z2-Z5), the person consults the librarian who diagnoses the zone of intervention from a query or a problem statement, and through an interview the background of the problem is elicited. That background information centers on four criteria that were found in the in the studies of the search process. These criteria can be used for making elaborative choices: the requirements of the task, the personal interest of the user, the time allotted for completion and the availability of information." (Kuhlthau, 1993, p, 158-159)

Senere fremgår det, at:

"Based on professional experience and theory, the librarian makes a diagnosis as to whether the problem is a product (source) or a process problem." (Kuhlthau, 1993, p. 159). 
Heraf følger, at de problemer, der kan løses gennem ordinering af "produkter" falder i et sted i zone 2-4, og bibliotekaren leder derfor brugeren til de rette kilder, og anbefaler eventuelt en bestemt rækkefølge i brugen af disse kilder (ibid.), i overensstemmelse med artikulationen af 'kognitiv udvikling' - lånt af Piaget/Bruner - som nævnt i analysen af momentet 'information'. Der etableres en modsætning mellem proces og information som håndgribeligt dokument - som produkt, da der - i tilfælde af, at brugerens problem falder i zone 5 - ordineres "proceshjælp", i stedet for "produkthjælp":

"When the user's problem is diagnosed as changing and uid the fifth zone of intervention (Z5) is necessary, the application of a process approach to mediation and education. The librarian enters into a dialogue with the user and the interaction extends over a period of time. The fifth zone of intervention (Z5) encompasses exploration and formulation for construction and learning in the Information Search Process. The anticipated outcome of the intervention is application of the user's new construction to the problem at hand." (Kuhlthau, 1993, s. 159)

Disse er udgangspunkt for den "diagnose", som bibliotekaren stiller, og for den hjælp, der gives i form af ordinering af "produkter" og en anbefaling af en bestemt rækkefølge i brugen af disse kilder (ibid.). Der etableres en modsætning mellem proces og information som produkt, da der - i tilfælde af, at brugerens problem falder i zone 5 - ordineres "proceshjælp", i stedet for "produkthjælp" (Kuhlthau, 1993, s. 159). Kuhlthau skriver, at:

"Intervention is negotiated between the user and the librarian, rather than prescribed as in the case with the physician." (Kuhlthau, 1993, s. 159).

Spørgsmålet er, om denne intervention er forhandlet mellem ligeværdige partnere. Ud fra et diskursteoretisk perspektiv betyder artikulationen af 'den re ekterende praktiker', at der skabes en forskelsrelation baseret på en lægeanalogi, hvor 'bibliotekaren' er lægen, og 'brugeren' er en klient, der skal diagnosticeres og have ordineret en bestemt behandling. Her er det er 'bibliotekaren' der definerer, hvilken type information eller procesvejleding, der er nødvendig i zonerne 2-5. Hertil kommer, at der via artikulationen af 'zonen for nærmeste udvikling' skabes endnu en relation mellem bibliotekaren og brugeren, hvor bibliotekaren positioneres som den voksne/læreren, der intervenerer $\mathrm{i}$ forhold til brugerens - barnets - læringsproces (Tuominen, 1997, s. 363).

Ud fra differenslogikken betyder det, at 'brugeren' og 'bibliotekaren' giver identitet til hinanden ved at stå i en forskelsrelation til hinanden. Det er netop i kraft af de forskelle, at hhv. 'brugeren' og 'bibliotekaren' betydningsfikseres og dermed får deres identitet. Det vil fx sige, at hvor bibliotekaren defineres som professionel, defineres brugeren følgelig om værende det, der er forskelligt fra dette dvs. lægmand. Dette gengives i figur 4 nedenfor:

$\begin{array}{lll}\text { 'Bibliotekaren' } & \neq & \text { 'Brugeren' } \\ \text { Læge } & \neq & \text { Klient/patient } \\ \text { Voksen } & \neq & \text { Barn } \\ \text { Sikker } & \neq & \text { Usikker } \\ \text { Professionel } & \neq & \text { Lægmand } \\ \text { Ekspert } & \neq & \text { Amatør }\end{array}$

Figur 4: Forskelsrelationerne mellem 'bibliotekaren' og 'brugeren' i Kuhlthaus diskursive artikulation. Tegnet $\neq$ står i denne sammenhæng for det modsatte af lighed - det vil sige forskel.

Kuhlthau benytter differenslogikken som diskursiv strategi, fordi hun tilsyneladende $\emptyset$ nsker at bevare og understrege forskellene mellem 'bibliotekar' og 'bruger'. Forskellene, der fikserer 'brugeren' og 'bibliotekaren' i foretrukne subjektpositioner, får lov at eksistere. På den måde opstår der et ulige afhængighedsforhold, hvor den ene positioneres som sikker - den anden usikker. Som følge af bibliotekarens position som værende sikker, samt som den der "ordinerer" den rette information, sikres biblioteka- 
ren en privilegeret position som "rådgiver" i forhold til brugeren (Kuhlthau, 1993, p. 154).

\section{Konklusion}

Jeg har forsøgt gennem en diskursteoretisk analyse at afdække, hvordan udvalgte LIS-begreber er blevet modificeret som følge af artikulationen af de læringsrelaterede begreber. Det har ikke mindst betydning for konstruktionen af 'informationssøgning' der defineres som læring, for momentet 'information' som mening/fortolkning, hvorved en traditionel betydningsfiksering af 'information' som håndgribelig entitet udelukkes, for relationen mellem 'brugeren' og 'bibliotekaren', hvor 'bibliotekaren' positioneres som sikker, 'brugeren' som usikker. Hertil kommer, at 'bibliotekaren' ser ud til at indtage en rolle som lærer i forhold til 'brugeren', hvorved det traditionelle skel mellem bibliotekar og lærer bliver udvisket.

Jeg mener, at Kuhlthaus import og artikulation af de læringsrelaterede begreber i relation til 'informationssøgning' har betydning for konstruktion af dette og andre begreber. Det er min vurdering, at Kuhlthaus artikulation er en konkret diskursiv artikulation, der får bestemte betydningsmæssige konsekvenser. Nodalpunktet i denne diskursive artikulation er 'informationssøgning', der eksplicit konstrueres som læring, og som derved fikserer andre momenter på bestemte måder. Kuhlthau er en hegemonisk agent, der forsøger at foretage en hegemonisk intervention. Forudsatningerne for at skabe en hegemonisk intervention kan identificeres i teksten; Kuhlthau udelukker det bibliografiske paradigme gennem udfoldelsen af ækvivalenslogikken som diskursiv strategi. Der etableres en antagonisme mellem brugerperspektivet og det bibliografiske paradigme og en kamp om betydning af elementer som 'informationssøgning', 'information', 'bruger' og 'bibliotekar'. Dertil kommer, at grænserne er ustabile og uafgørlige; der er ikke tale om en endelig lukning og betydning af fiksering: Kuhlthau trækker tilsyneladende uønskede betydninger af momentet 'information' ind. Endelig kan der identificeres tegn på, at det bibliografiske paradigme og de bibliotekarroller, der ækvivaleres med dette, dislokeres af fremkomsten af informationsalderen/ informationssamfundet. Det bibliografiske paradigme kan ikke rumme de begivenheder og betydninger "informationssamfundet" repræsenterer (Kuhlthau, 1993, s. 168-187).

Kuhlthau trækker på Sense Making, samt på artikulationen af elementer hentet fra det kognitive synspunkt, sammen med de læringsrelaterede begreber. Faktisk bekræfter netop de læringsrelaterede begreber, som Kuhlthau henter ind fra det videre diskursive felt det kognitive synspunkt og vice versa. Derfor kan der ikke være tale om nogen epokegørende ny reartikulation af elementer til momenter. Idet Kuhlthau nok distancerer sig fra det bibliografiske paradigme gør hun dette ved at trække på det kognitive synspunkt, der er en veletableret hegemonisk diskurs i LIS. Kulthaus artikulation af læringsrelaterede begreber er ikke den eneste der finder sted i diskursordenen IBR. Andre læringsrelaterede begreber artikuleres på andre måder og med anvendelse af andre diskursive strategier. Hvorom alting er kan Kuhlthau-teksten ses som eksempel på, at det kan have konsekvenser at importere læringsrelaterede begreber $\mathrm{i}$ forbindelse med informationssøgning. Nogle af disse konsekvenser er eksemplificeret og afdækket i denne artikel.

Jeg har bevidst undladt gennem analysen at tage normativt stilling til, hvorvidt de læringsrelaterede begreber er relevante for LIS og for vores forståelse af informationssøgning. Jeg har tilstræbt at analysere, hvordan begreber hentet fra læringsteori relateres til informationssøgning. Formålet med artiklen er dog en opfordring til at debattere konsekvensen af at anvende læringsrelaterede begreber i LIS. Det er denne artikels pointe, at vi bør være opmærksom på og diskutere de begrebsmæssige og betydningsmæssige konsekvenser import og implementering af begreber hentet fra domæner uden for LIS har for faget og dets kernebegreber. Det betyder naturligvis ikke, at jeg mener, at man ikke bør hente inspiration i andre faglige domæner. Jeg vil blot understrege nødv- 
endigheden af at gøre sig klart, hvad konsekvenserne af disse applikationer er.

\section{Litteratur}

Belkin, N. (1990). The cognitive viewpoint in information science. Journal of Information Science, 16(1), $11-16$

Buckland, M. (1991). Information and information systems. Westport, Conneticut : Praeger Publishers

Capurro, R. (1992). What is Information Science for? A philosophical re ection. I: Vakkari \& Cronin (Eds.), Conceptions of Library and Information Science: Historical, empirical and theoretical perspectives. Proceedings of the International Conference held for the celebration of 20th Anniversary of the Department of Information Studies, University of Tampere, Finland, 26-28 August 1991 (s. 82 - 96). London : Taylor Graham

Ellis, D. (1992). The Physical and cognitive paradigms in information retrieval research. Journal of Documentation, 48(1), 45 - 64

Frohmann, B. (1992). The power of images: A discourse analysis of the cognitive viewpoint. Journal of Documentation, 48(4), 365 - 86

Gazel, K. (2003). Informationss $\phi$ gning som laring: En diskursteoretisk analyse af artikulationen af laringsrelaterede begreber $i$ relation til informationssøgning. København : Danmarks Biblioteksskole. Specialeafhandling

Hjørland, B. (2000). Library and information science: Practice, theory and philosophical basis. Information Processing and Management, 36(3), 501 $-531$

Howarth, D. (2000). Discourse (s. 101 - 142). Buckingham : Open University Press
Howarth, D., \& Stavrakakis, Y. (2000). Introducing discourse theory and political analysis. I: D. Howarth, A. J. Norval \& Y. Stavrakakis (Eds.), Discourse theory and political analysis: Identities, hegemonies and social chance (s. 1 - 23). Manchester : Manchester University Press

Ingwersen, P. (1995). Information and Information Science. I: A. Kent (Ed.),

Encyclopedia of Library and Information Science, vol. 56, suppl. 19 (s. 137 -174). New York : Marcel Dekker

Kuhlthau, C. C. (1993). Seeking Meaning : A process approach to library and information services. Norwood, N.J. : Ablex

Laclau, E., \& Mouffe, C. (2002). Det radikale demokrati: Diskursteoriens politiske perspektiv (s. 11 -100). Frederiksberg : Roskilde Universitetsforlag

Talja, S. (1997). Constituting "Information" and "User" as research objects : A theory of knowledge formations as an alternative to the information mantheory. I: P. Vakkari, R. Savolainen \& B. Dervin (Eds.), Information Seeking in Context. Proceedings of an International Conference on Research in Information Needs, Seeking and Use in Different Context, 14-16 August 1996, Tampere, Finland (s. 67 -80). London : Taylor Graham

Torfing, J. (1999). New theories of discourse: Laclau, Mouffe and Žižek. Oxford : Blackwell Publichers

Tuominen, K. (1997). User-centred discourse: An analysis of the subject positions of the user and the librarian. Library Quarterly, 67(4), 350 - 371

Wilson, T. (1997). Information behaviour : An interdisciplinary persective. I: P. Vakkari, R. Savolainen \& B. Dervin (Eds.), Information Seeking in Context. Proceedings of an International Conference on Research in Information Needs, Seeking and Use 
in Different Context, 14-16 August 1996, Tampere, Finland (s. 39 - 50). London : Taylor Graham
Winther Jørgensen, M., \& Phillips, L. (1999). Diskursanalyse som teori og metode. Frederiksberg : Roskilde Universitetsforlag. 